\title{
Teknologia avoin, tiede salattu
}

Kun aloitin opintoni Helsingin yliopistossa 1990-luvun lopulla, Internet oli vielä nuori. Tai ainakin meille nuorille opiskelijoille se oli uusi ja outo keksintö, jonka merkitys tieteenteon tai edes kommunikoinnin apuvälineenä ei ollut vielä oikein avautunut. Kandiseminaarissa opettaja kuitenkin kehotti katsomaan Internetistä mahdollisia lähdeartikkeleita tutkielmaa varten. Opiskelija-asuntolassani ei tuolloin vielä nettiä ollut, joten heti seuraavana viikonloppuna matkustin vanhempieni luokse testaamaan hakuja. Modeemi sirisi ja surisi ikuisuuden, kunnes lopulta pääsin kokeilemaan kirjoittaa "Tolstoi" tai "Tolstoy" (kyrilliikkaan ei tuolloin vielä tietokoneemme kääntynyt) erilaisiin hakukoneisiin: Altavistaan, Hotbotiin, Yahoohon ja Googleenkin. Mutta pettymys oli suuri kun ainoat järkevät tulokseksi saadut linkit käsittelivät vain lyhyesti luonnehtien sitä, kuka Leo Tolstoi oli, missä ja milloin eli ja että hän kirjoitti sellaiset teokset kuin Anna Karenina ja Sota ja rauha. Kandityöni aiheen, Tolstoin "Djavol"-novellin feministisen lähiluennan, kannalta tällaisella pintatiedolla ei ollut mitään arvoa. Tietokoneen ääressä vietetyn lauantai-iltapäivän lopputulema oli yhtä tyhjän kanssa. Lopulta ainoan todella hyödyllisen lähteen tutkielmaani sain ystävältä, joka otti paperikopion omasta lähikirjastostaan löytämästään artikkelista ja lähetti sen minulle kirjepostina. Tämä ensimmäinen kokemukseni teknologian, tutkimustyön ja tiedonsaannin parissa jätti minut täysin vakuuttuneeksi siitä, että ihmeellinen Internet on tieteenteossa täysin hyödytön.

Vuosikymmen myöhemmin, 2000-luvun lopulla, suhteeni internetiin (nyt jo pienellä kirjaimella kirjoitettuna) - ja tieteenkin tekemiseen - oli jo toisenlainen. Aloittelevana väitöskirjantekijänä tavoitteeni ei ollut enää ainoastaan hakea tietoa vaan myös jakaa sitä. Olin kirjoittanut opiskelijalehteen muutaman mielestäni sangen onnistuneen tekstin, joita halusin jollain lailla nostaa esiin ja vaalia. Artikkelit venäläisen kauhuelokuvan historiasta sekä tuolloin vielä ei-niin-legendaarisen ohjaaja Aleksei Balabanovin uudesta elokuvallisesta äänestä olivat vaarassa jädä paperilehden sivuilla vain hetken lapsiksi, jotka pian vaipuisivat unholaan. Erityisesti kauhuelokuva-artikkeli ja siihen koottu tieto oli ollut suuren kirjallisen ponnistelun takana, sillä vielä tuolloin ei internetistä löytynyt marginaalisempaan aiheeseen tietoa valmiina pakettina. Ratkaisuksi tekstien ekstinktio-uhkaan keksin perustaa yliopiston palvelimelle omat kotisivut, joita varten opettelin xhtml-kieltä Jukka K. Korpelan mainiosta opaskirjasta Web-suunnittelu. Ajatukseni oli, että silloin jo pitkälti Googleen keskittyvä hakukonemaailma löytäisi nettiin laitetut tekstini, tarjoaisi niitä suomenkielisille Balabanovista ja 
venäläisestä kauhuelokuvista kiinnostuneille ihmisille ja näin hyvän tiedon määrä maailmassa kasvaisi. Oli hetki, jolloin tuntui että tiedon välittämisen teknologia avasi kokonaan uuden maailman, jossa kaikki oli mahdollista.

Reilusti yli kymmenen vuotta myöhemmin voin nyt todeta, että en ole varma onko näitä luomiani sivuja tai tekstejä koskaan löytänyt kukaan. Ja tunnustettava on, että kotisivukokeilu jäi pitkälti unholaan myös minulta itseltäni. Tänä keväänä kuitenkin muistin sen uudestaan kun pähkäilin tiedemaailman nykyisen julkaisupolitiikan mielettömyyttä. Yhteistyössä Tekniikan museon Emilia Västin kanssa olin juuri saanut valmiiksi tekstin, jonka tavoitteena oli toimia keskustelunavauksena keksijä E. M. C. Tigerstedtin elämäntyöstä elokuvan ääniteknisen kehityksen parissa. Kyseessä ei ollut vertaisarvioitu artikkeli, mutta silti pienenäkin kirjoituksena vakava pyrkimys aitoon keskusteluun tiedeyhteisön kanssa; toiveena että joku innostuisi, reagoisi ja tarttuisi aiheeseen vieden sitä pidemmälle ja syvemmälle. Loppujen lopuksi sitähän me kaikki tutkijat tutkimuksemme parissa toivomme - että julkaisu olisi keskustelun alku eikä sen päätepiste. Mutta jälleen kerran ongelmaksi muodostui tieteen ja teknologian problemaattinen yhteispeli: koska teksti ei ollut osa mitään erikseen rahoitettua projektia, ei meillä kirjoittajilla ollut tarjota julkaisijalle tuhansien dollarien summaa vastineeksi siitä, että ihmiset pääsisivät lukemaan sen. Näin englanninkielisessä kansainvälisessä tieteellisessä lehdessä julkaistu tekstimme jäi yhdeksi internetin lukemattomista maksumuurien taakse haudatuista salatuista artikkeleista. Internet on tiedonlähteenä ikään kuin sulkenut ympyränsä: aluksi kaikki oli avointa, mutta tiedon määrä oli hajanainen ja vähäinen, ja nyt kun periaatteessa kaikki olisi mahdollista saada käden ulottuville ja napin painalluksen päähän - siitä tehdäänkin säännöstelty privilegio, jossa jonkun täytyy maksaa. Joko tiedon tuottajan tai sen vastaanottajan.

Yhtäkkiä pienet ja vaatimattomat kotisivuni muodostuivat pelastusköydeksi ammatillisen epätoivon keskellä. Ryhdyin kertaamaan kymmenen vuotta vanhaa html-koodaustaitoani joka on ehkä jo kielenä vanhentunut, mutta yksinkertaisuudessaan silti toimiva ja ajaton. Onnistuin selvittämään, minkä työstövaiheen tekstin kotisivuilla voi julkaista ilman, että joudun vaikeuksiin oman tekstini luvattomasta julkituonnista. Tosin edelleenkään en ole täysin varma menikö prosessi kaikilta osiltaan oikein - muuten kuin eettisesti ja moraalisesti. Joka tapauksessa muutaman viikon iltapuhteina tehdyn uurastuksen tuloksena Tigerstedt-teksti on nyt vapaasti luettavissa html-muotoisena netissä. Hetken tunsin olevani kuin Aleksandra Elbakjan, kazakstanilainen avoimen tieteen piraattikuningatar, jonka kymmenen vuotta sitten koodaama Sci-Hub -artikkelitietokantasivusto kattaa nykyisin joidenkin arvioiden mukaan jopa $85 \%$ kaikista alunperin maksumuurin takana julkaistuista tieteellisistä teksteistä. Seuraavana hetkenä mieleni valtasi pelko - kunhan ei vain kävisi kuin yhdysvaltalaiselle hakkerimarttyyri Aaron Swartzille, joka vuonna 2013 joutui oikeuden eteen JSTOR-tietokannan artikkeleiden laajamittaisesta luvattomasta jakelusta ja päätyi riistämään oman henkensä.

Yli kaksikymmentä vuotta oman ensinettikosketukseni jälkeen ymmärrän hyvin, että internet ei ole tieteen teossa suinkaan hyödytön, vaan se on sen ennennäkemätön mahdollistaja ja demokratisoija. Turhautunut nuori minäni oli siis väärässä - mutta vain osittain. Internet ei ole hyödytön, mutta olennaista on sisältö mitä sinne laitamme - ja kenet se saavuttaa. Onko tieteellinen sisältö vain vihkiytyneitä tieteilijöitä varten? Halutaanko nostaa muureja ja kynnyksiä vai madaltaa niitä? Minä toivon, että jos tällä hetkellä joku jossain päin maailmaa suunnittelee tekevänsä opinnäytteen tai on muuten vain kiinnostunut vaikkapa varhaisen elokuvaäänen kehityksestä, hän googlettamalla löytää tekstini ja sitä kautta pääsee hartaudella kuratoimani tietopaketin äärelle, jonka avulla on toivottavasti sitten helpompaa kurottaa 
vielä syvemmälle - ilman esteitä, ilman muureja, ilman salakoodeja. Ei tutkittu tieto saa olla salatiedettä, se kuuluu kaikille.

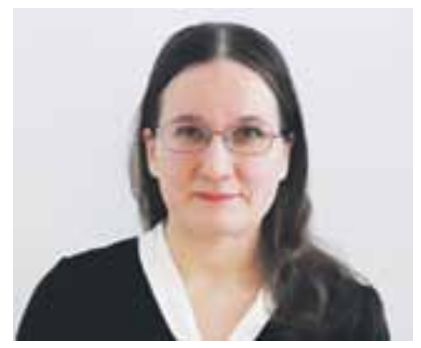

Ira Österberg

Kirjoittaja työskentelee tällä hetkellä Helsingin yliopiston Aleksanteri-instituutin tutkimuskoordinaattorina sekä Idäntutkimuksen toimitussihteerinä. 